\title{
Childhood Learning vs. Adulthood Learning: The Theory of Pedagogy and Andragogy
}

\author{
Simeon O. Edosomwan \\ North Dakota State University, North Dakota, USA
}

\begin{abstract}
From time in memorial, learning as a construct has been a significant and fundamental part of human growth, and development. But understanding and harmonizing the context of learning in childhood and adulthood can present a complex scenario. This paper reviewes three theories of childhood learning vs. adulthood learning and compare them to the theory of pedagogy and andragogy in education. It finds using reflective discourse and document analysis, that while there are distinction in pedagogy and andragogy, in the same vain; both concepts can also connect and overlap in learning circumstances and practical applications in education. This is important in understanding the modern child and adult learner.
\end{abstract}

Keywords: adulthood, andragogy, ahildhood, learning, pedagogy

\section{Introduction}

What is learning? Learning is a very complex phenomenon, as there is no one general definition delimited to the construct of learning (Smith, 1982). From a realist constructivist viewpoint, learning as a construct, exists as a multi-dimensional construct, therefore, scholars define learning from different perspectives. What is important is that, from time in memorial learning has been a significant part of human development and growth. Being it as a child, emerging adult, or a matured adult of 25 years older. Historically, learning can be associated to how we know and form our concrete realities. Learning in this sense includes all formal and informal inquiries. Learning was also defined as central to developing important life competencies to function in the society (Bransford, Brown, \& Cocking, 1999). Were-in, knowledge and skills are acquired to function in the real word. Like an adult learner learning to fly an airplane, but first, must learn the theoretical aspect of flying an airplane before the practical act. Learning has also be perceived as a "process of mental inquiry" (Knowles, Holton, \& Swanson, 2012). In which case, we intrinsically sought to know and our brain and cognitive plays significant role in assimilating knowledge (Perry, 1999). Using our minds, emotions, intellect, and psychological faculty. Under this condition also, the entire mental capacity is put into motion when learning and assimilating new information. In another definition, learning was perceived as the "continuous interaction among cognition, emotions, and social context” (Merriam, Caffarella, \& Baumgartner, 2007). Social context in this regards means our environment where this continuous interaction takes place. And lastly, learning has been defined as the process by which behavior, knowledge, skills, and attitudes are acquired (Boyd, Appss, \& Associates, 1980). In this case, learning takes the form of behavioral adjustment, change in perspectives, skill

Simeon O. Edosomwan, doctoral student, NDSU Education Doctoral Programs; graduate teaching assistant, dean's office, School of Pharmacy, North Dakota State University. 
acquisition, new knowledge, and the development of new approaches and ways of thinking.

In acquiring knowledge, while childhood learning transit, adulthood learning persist and continue through-out life time. Given the relevant nature of learning, this study explores three childhood and adulthood learning theories and compare them to the theory of pedagogy and andragogy using literature in human development and adult learning to engage in reflective discourse and document analysis. This is important in order to expand our knowledge on the contemporary stages of childhood and adulthood learning. This knowledge is also important in understanding childhood learners and adult learners in educational settings. And lastly, it is important in meeting learning and developmental needs in diverse learning situations.

\section{Maturation Learning Theory}

The maturation learning theory and development was advance by American psychologist Arnold Gesell (1890-1961) who promoted the theory that childhood learning and development is based on biology, children alternate between good and bad years in development and that body types correlates with personality development (Thomas, 1992). According to the maturation theory, which focuses on physical and mental development, Gesell (1948) saw developmental patterns been determine by a "child's hereditary." This perspective implies some personal traits are natural, traditional, inborn, inherited, and transmissible. For example, a child who completely looks and acts like the father or mother right from infancy might have inherited some traits that account for acting in such manner. Or, a child who completely behaves like a relative in the family even if that child has not had prior encounter with the said relative. Marchese (1995) noted that Gesell was guided by maturational conception of children development in conceiving the theory. Growth, Gesell defined as the process, so intricate and sensitive that there must be powerful stabilizing factors, intrinsic (inborn) rather than extrinsic, which preserve the balance of total pattern and the direction of the growth trend (Marchese, 1995). Maturation is a name for this regulatory mechanism. Arnord Gesell (1890-1961) developed this theory after he observing and recording the changes he noticed in the growth and development of children from infancy through adulthood (Farr, 2014). Dalton (2005) wrote that, Arnold Gesell observational studies on how infants grow, attain motor coordination, and learn new skills furnish the first comprehensive theory of interrelated sequences through which infants and children pass in their physical and mental development. He provided a scientific foundation for the diagnosis and preventive clinical care of pre- and post- natal infants that has become hallmark of modern pediatrics. Like others, Dalton (2005) believed that maturation theory has help in understanding childhood learning and development and some of the inherent complications observe in some children. A closer look at an individual today will present some hereditary features for understanding why such personality behaves the way they do or learn the way they learn. Although maturation theory continue to affect what goes on in childhood education, it has also been critique for taking the stance that environment has no effect on a child's development and attribute all aspects of the learning process to genetics factors (Dalton, 2005). While maturation learning theory has provided substantial evidence of some inherent traits one may possess, the environmental learning theory is also worth exploring in understanding the multiple nature of learning and development.

\section{Environmental Learning Theory}

Many scholars and theorists would agree much of what laid the foundational framework for understanding the transformation of childhood learning and the school readiness program in America, is largely attributed to 
the environmental learning theory. As highlighted by Lipoff (2011), environmentalists believes that the environment shapes childhood personality, learning, and behavior. She argued that the environment which encompasses everything that surrounds the child is of great influence. And that behavior and learning are reaction to the environment. This assumption though significant in learning context, it raises lots of questions. E.g., how does the environment influence learning? Does some environment prepare one for greater success in life due to what is learnt, while others does the opposite? Does the environment determine a person's intelligence or non-intelligence? etc.. This knowledge means a lot to parents, and educators in understanding how the child's environment also shapes attitude, values, and conduct.

Bandura (1977), one of the social environmentalist, that develops the social learning theory discover after observing a group of kids, that behavior is leant from the environment though the process of scaffolding and observational learning. For instance, he found through observational learning, that the young child observes and copy behavior of others, leading to decision-making skills and development. This individuals that are observed are called models (McLoed, 2011). I.e., parents, teachers, educators, and older adults that the child sees. Contemporarily, social and mass media have also contributed to observational learning and its impact on childhood development.

\section{Constructivist Learning Theory}

The constructivist learning theory embraces a number of related learning approaches and was advance by scholars, such as Jean Piaget, Maria Montessori, and Lev Vygotsky. Their works differ on focus and aspects of constructivist learning, but each articulate in essence, constructivist perception of learning and development in childhood. They are incessant in their beliefs that learning and development occurs when young children interact with the environment and people around them (Hunt, 1969). This interaction could be social as advance by Lev Vygotsky or cognitive as describe by Jean Piaget. Constructivist theorists believe that just like adults, children develop knowledge through interaction and active participation in their learning (Weegar \& Pacis, 2012). Particularly, Lev Vygotsky (1896-1934), the Russian psychologist postulated the socio-cultural learning theory to establish the active participation through interaction. Vygotsky viewed learning as a social process, that is achieve through interaction with more knowledgeable members of the culture or society (Weegar \& Pacis, 2012). Which can be interpret as adults. Vygotsky proclaimed childhood learning which played a fundamental role in cognitive development occurs on two cultural plane (inter-psychological and intra-psychological plane). At the early stage, the child is completely dependent on other people, usually the parent, who initiates the child's actions (Turuk, 2008). While citing Vygotsky, Wertsch (1985) stated that the child acquires knowledge through contacts and interactions with other people as the first step (inter-psychological plane), then later assimilates and internalizes this knowledge (intra-psychological plane). The inter-psychological planeis where the initial conceptualization and gravitation of learning takes place in childhood through the first interaction. Turuk (2008), Vygotsky claimed that the transition from social to personal property is not a mere copy, but a transformation of what has been learnt through interactions, into personal values. The second idea advanced by Vygotsky in constructive learning theory is that, the potential for cognitive development in childhood learning is limited to a "zone of proximal development" (ZPD). This ZPD is the area of exploration for which learners are cognitively prepared but requires help and social interaction to fully develop and function (Briner, 1999). The constructive learning theory builds the foundation that help us understand the dynamics of learning activities during childhood learning. Children build their own knowledge 
by interacting and making sense of the world, and continuously incorporating new beliefs and ideals by their interaction with the environment. This knowledge is useful as childhood learning transit into adult learning.

\section{Adulthood Learning Theory}

Learning in adulthood is an intensive personal initiative and for the most part self-directed. Yet, the response to contemporary adult learning is overwhelming and interesting. Today, more than ever, societies depend on adult learning to disseminate information, advance knowledge, develop new skills, and shape attitudes around the globe. Stubblefield and Keane (1994) noted that, "The belief that education must extend through adulthood is now a commonplace." For the first time, in American history for example, adults outnumber youth population (Merriam et al., 2007). The implication is learning in adulthood can no longer be circumvented or treated with levity. It also necessitate using learning processes to help adults navigate this new circle or life span, cope with social and societal adult demands, become more productive, enjoy life, and understand the world of adults in general (Stubblefield \& Keane, 1994). Changing demographics, globalization, and advances in information technology also presents the context for cogitating adult learning more than it has ever been. Consequently, these context are inevitably shaping adult learning needs in today's world (Merriam et al., 2007). Therefore, understanding adult learning which is at the center of all learning activities as observes by Merriam et al. (2007) becomes a pivotal scene in navigating knowledge both at the formal, informal, and non-formal levels of education. This is also important, because adult learning is contextual and complex. As a result, several adult learning theories and literatures has now emerge to help us better comprehend learning in adulthood.

\section{Jarvis Learning theory}

Jarvis learning theory is a theory of adult learning. The theory was developed by a Briton professor Peter Jarvis who had a background in theology and sociology, but later became interested in learning theories primarily in adult education (Illeris, 2009). According to Jarvis learning theory, all learning begins with an adult life situation or put differently "adult life experience." Merriam et al. (2007) had earlier stated that "all adult learning begins with "life experience'." It is mean that life experiences play a significant role in adult learning. Professor Jarvis explained further by giving an analogy that, "When my grandson comes home from school, we often ask him — what did you learn at school today? And, we expect a response! But if we ask adults - what have you learned from life recently? We might receive a different response" (Jarvis, 2012). He argued that many adults that may be ask to write down learning events finds it extremely difficult because a great deal of our everyday learning is incident, pre-conscious, and unplanned. However, learning is about life (Jarvis, 2012) and life is full of experiences and learning opportunities. Learning, according to Jarisis, both existential and experiential (Illeris, 2009). Which implies, learning exists in the present and first hand realistically. Jarvis (2012) continued all learning begins with the five human sensations of "sound, sight, smell, taste, and touch." Usually, the sensation is unfamiliar at first. For example, learning a new word that has not be held before. In this instance, experience is a matter of the body receiving this unfamiliar sensation and transforming these sensations into the language of the brain and mind, and learning to make them meaningful. This is believed to be the first stage in human learning (Illeris, 2009). Jarvis also believed that learning is dependent on the body and biology is a prominent factor in the learning process. Not precisely, as a result of the gene, but how the human senses function. This is somewhat different in childhood learning theory which attributes aspects of childhood learning and development to gene or hereditary. 
Furthermore, in adulthood, some life experiences occurs repeatedly that they are taken for granted and as such, they do not lead to learning experiences. When this happens, Jarvis tagged this to be "a disjuncture." Merriam et al. (2007) from a different perspective asserts this phenomenon as one of the fundamental condition for learning to occur. Merriam et al. (2007) also believed that the learner which is not a cognitive machine but a whole person encounters an experience in his/her social context that creates disjuncture between biography and experience, a state that triggered learning for dealing with the situation. Conversely, it is important to stress that, if the individual chooses to ignore, no profitable learning may occurs instantly.

In summary, the Jarvis learning theory create a critical context for reflecting and understanding adult learners. Because transforming experience into knowledge, attitudes, values, feelings, and responses is the goal of learning. Therefore, any situation can be turn into learning experience or a missed opportunity. To learn something new, there must be social interaction and disjuncture, people must make use of their sensation to stop and think in making connection during the learning process.

\section{Transformative Learning Theory}

Transformative learning theory is an adult learning theory that changes the way individuals think about themselves and their world. This involves a shift of consciousness. For instance, English language learners often report a shit in their views of United States (U.S.) culture and in their view of themselves as they gain confidence communicating in a new language (King, 2000). The transformative adult learning theory was developed by Mezirow (1975) when he studied diverse group of women returning to postsecondary study and workplace after a lengthy time out. In an effort to address, the needs of some U.S. women who were resuming their education and employment, he conducted a qualitative study to identify factors that characteristically impede or facilitate women progress in the re-entry program (Kicthenham, 2008). According to the transformation adult learning theory, there are 10 steps or phases often explicit to transformative learning (Merriam et al., 2007). They are: (1) a disorienting dilemma; (2) self-examination of feeling guilt or shame; (3) critical assessment of epistemic, sociocultural, or psychic assumption; (4) recognition that one's discontent and the process of transformation are shared and that others have negotiated a similar change; (5) exploration of options for new roles, relationships, and actions; (6) planning for a course of action; (7) acquisition of knowledge and skills for implementing one's plan; (8) provisional trying of new roles; (9) building of competence and self-confidence in new roles and relationships; and (10) a reintegration into one's life on the basis of conditions dictated by one's perspective. Learning experience occurs in any of these steps. However, there are four main components to transformative learning (Merriam et al., 2007). Experience, critical reflection, reflective discourse, and action. What is fascinating and instructive is the repeated pattern and mention of experience in adult learning. This is to call for critical reflection to constantly cogitateone's experience, so as to get the best out of learning since all learning begins with experience (Jarvis, 2012). This epistemological view may sound subjective, but it makes sense since there are multiple ways of knowing. What people encounter, places they have been, and what happens day to day, formal or informal, conscious or unconscious shapes what individuals ways of knowing (Merriam et al., 2007). Freire (1970) also supported this idea when he thought, "Education does not stop in the classroom but continues in all aspects of learner's life." In education, for example, educational policies are formulated as a response to shape experiences either to discontinue a particular approach or strengthen such practices and this comes from experience. In this regards, for transformative learning to occur action is required to shape the learners experience (Merriam et al., 2007). In 
the area of disorienting dilemma, transformational learning which occurs after a major life crisis, involves experiencing a deep structural shift in the basic premises of thoughts, feelings, and actions. This shift leads to consciousness that dramatically and permanently alters our being (Illeris, 2009). Transformative learning may also result in instrumental learning (Illeris, 2009). In this case, task orientated and critical self-reflection will transform the learner. In all transformative learning has been successful in working with most adults and continue to help adults actualize the goal of learning.

\section{Humanistic Learning Theory}

Humanistic learning theory view adult learning from the perception of human experience, potential for growth and development (Merriam et al., 2007). This perspective is value driven and was advanced in humanistic philosophy many centuries ago before it became popular in the late 1950s. It has as a central focus of the total enhancement, dignity, freedom, and growth of the human personality. It assumes that human beings behave out of intentionality and value (Kurtz, 2000). And, because humanistic learning theory is value base, adult learning is driven intrinsically and directed inwardly. Although external factors could also condition adult learning.

In the 1950s, the philosophical paradigm of humanism gained influence to inform the theoretical foundation of the works of scholars, like Abraham Maslow and Carl Rogers, who believe that human beings can control their own destiny, be good, and strive for a better world (Rogers, 1983). In their assertion, learning is a personal act to fulfill one's potentials, therefore, people are free to act, and behavioris as a result of human choices (Rogers, 1983). This conceptualization of humanistic adult learning is worth appraising, because it addresses adult learning from a holistic perspective. Also, most adult learning today is premeditated on adult learner's motivation to either improve themselves, fulfill literacy and educational demands as goal-directed individuals, respond to life changes, enhance employment opportunity, personal and professional development, or love for life-long learning. If one stops and takes a reflective step back to determine why he/she personally engages in learning as adult, undisputedly you will discover you fall into one of such categories. For Maslow and Rogers, adult learning is preempt on the value of experience, freedom, and self-directedness in the learning process (Merriam et al., 2007). As stated by Gage and Berliner (1991), there are five basic objectives of humanistic learning: (1) To promote positive self-direction and independence to develop human regulatory system; (2) To develop the ability to take responsibility for what is learned; (3) To develop creativity to enhance thinking skills of our cognitive; (4) Curiosity for explorative behavior; and (5) An interest in art to develop the affective and emotional systems. Under this assumption, adults will learn best what they want and need to know especially as self-directed learners. Some common assumption of humanism, include the quest for the good life, is central to the task of mankind and in learning. Individuals have the capacity within them the power for achievement, they are responsible for the realization of the world they dream. Intelligence and the will of task must be determine (Humanist Manifestos I and II, 1973).

At the height of humanistic theory of learning, was Abraham Maslow theory of self-actualization, in which he theorized about the hierarchy of needs and self-fulfillment (the tendency to actualize one's potentials) (Maslow, 1943). Maslow theory is based on the notion that experience is the primary phenomenon in the study of human learning and behavior. According to him, "What a man can be, he must be." Therefore, the goal and the purpose of learning/education is self-actualization (Elias \& Merriam, 2005). In order to bring about the development of persons who are open to change, continue learning, and become persons who can live together 
as fully functioning individuals. To realize this goal of learning in adulthood, adult learners and educators who work with adults should think in terms of bringing about intrinsic rather than extrinsic learning. These are two obvious motivational perspectives that can be drawn from Maslow self-actualization theory. These are: (a) learning to be a human being in general; and (b) learning to be this particular human being (Maslow, 1976). He also placed emphasis on choice, creativity, values, and self-actualization as distinctive human qualities and believed that meaningfulness and subjectivity were more important than objectivity (Merriam \& Caffarella, 1991). While Maslow felt self-actualization is an adult episode and did not occur in young people (Elias \& Merriam, 2005). This position can be subjected to research and future discussion.

It was Maslow's study of extraordinary adults, such as Lincoln, Beethoven, and Schweitzer, which led to personality traits deduction of self-actualize persons as: realistically oriented, spontaneous in thinking, emotions, and behavior. They are adults who are problem-centered to task, duty, and dedication to human course. Furthermore, they are autonomous, independent in learning, and remain true to themselves in the face of rejection. With self-actualize persons, there is a sense and feeling of identification with mankind and concern with the welfare of human race as a whole rather than their immediate constituent (Maslow, 1954). Within these category are adults who often engage in global and social learning programs that provides solutions to human problems, and promotes diverse initiatives across the globe. The foundation of their activities is developed and strengthened from a humanistic paradigm. Thus, we see the humanistic approach to adult learning is all embracing and help the adult learners think of learning from a place of value and fulfillment.

\section{Pedagogy and Andragogy}

Pedagogy as often consider by scholars as art of teaching is the classical teaching approach informing childhood learning. Andragogy on the other circuit is the art and science of teaching and learning strategy adopted for adults learners. An extension of andragogy has now emerged "heutagogy." Blaschke (2012) defined heutagogy as a form of self-determine learning with practices and principles rooted in andragogy. She continued that "based on the Greek for self," Hase and Kenyon (2000) also defined heutagogy as the study of self-determined learning. Similar to andragogy, in heutagogy, the instructor also facilitate the learning process only by providing guidance and resources, but fully relinquishes ownership of the learning process to the learner, who negotiates learning and determines what will be learnt and how it will be learnt (Hase \& Kenyon, 2000). This scenario is similar to online distance education, graduate students dissertation process were after receiving all the guide and resources in learning programs, the student gets to choose and decides on his or her dissertation. Then, decide on the mode and manner it will be studied. Online and distance education platforms that uses blackboard or other learning modes were learning resources are given to the adult learner also follow this order (heutagogy). In Blaschke (2012), a key concept in heutagogy is the double-loop learning and self-reflection. In double-loop learning, learners consider the problem and effects and outcomes, in addendum to reflecting upon the problem solving process and how it eventually influence the learner's own beliefs and actions.

\section{Applying Pedagogy and Andragogy in Learning Context}

From the theories reviewed, it is obvious that there is a distinction between childhood learning $v s$. learning in adulthood. It is also the same, when pedagogy is compare to andragogy. What is also obvious and less emphasis is the overlapping functions, these theories can play in learning situations if adopted. Pedagogy and 
andragogy can be substituted in learning circumstances for both childhood and adulthood learning. For example, the environmental learning theory has as it central focus on learning from the environment through interactions. Just like the child, adults can be seen to learn from interactions as much as children do. Adults learn from what they hear, see, sense, and feel in the environment. Adults also learn from modeling and observation as well as children do in the social learning theory (McLoed, 2011). And lastly, self-directed learning, one of the central ideas of andragogy is fast becoming not only an adult phenomenon, but also childhood practice. Many children are becoming self-directed learners who can put together puzzles and solve problems without any aid. Given these developments and findings, it is recommended that pedagogy and andragogy be applied in learning situations simultaneously depending on the learning objective and outcome. While pedagogy should not be solely stricted to childhood learning, so also, andragogy should not be exclusive to adults learning.

\section{Conclusion}

This paper reviewed three childhood learning and adulthood learning theories, and compared them to the theory of pedagogy and andragogy in education. The paper conclude that in childhood learning, learning is characterized with development, environmental interactions, scaffolding, and observations for learning to occur. Childhood learning also relys on modelingactivities in experiencing learning. As Albert Bandura (1977) established in social learning theory, children learn by observing others. This knowledge provides greater insights for understanding childhood learning, especially as the larger proportion of the society transit to adulthood. In adulthood learning, learning is distinguish by life experiences, both conscious and unconscious episodes, transformation, self-directedness, and self-actualization. This conceptualization of adult learning is essential in meeting human needs both on individualistic and community platforms. What is interesting to note, is the usefulness and overlapping roles each of these learning theories could play both in childhood and adulthood learning context. Leading to the assumption that pedagogy and andragogy can be applied simultaneously both in childhood learning and adulthood learningsituations.

\section{References}

Bandura, A. (1977). Social learning theory. New York, N.Y.: Routledge Falmer.

Blaschke, L. M. (2012). Heutagogy and life-long learning: A review of heutagogical practice and self-determined learning. The International Review of Research in Open and Distributed Learning, 13(1), 56-71

Boyd, R. D., Appss, J. W., \& Associates. (1980). Redefining the discipline of adult education. San Francisco, C.A.: Jossey-Bass Publishers.

Bransford, T. D., Brown, A. L., \& Cocking, R. R. (Eds.). (1999). How people learn: Brain, mind, experience and school. Washington, D.C.: National Academy Press.

Briner, M. (1999). What is constructivism? University of Colorado at Denver School of Education. Retrieved from https://curriculum.calstatela.edu/faculty/psparks/theorists/501 const.htm

Dalton, T. C. (2005). Arnold Gesell and maturation controversy. Integrative Physiological and Behavioral Science, 40(4), $182-204$.

Elias, J. L., \& Merriam, S. (2005). Philosophical foundations of adult educations (3rd ed.). Malabar, F.L.: Krieger Publishing.

Farr, T. (2014). Child development theories for parents and educators: An overview. Retrieved from https://blog.udemy.com/ child-development-theories/

Friere, P. (1970). Pedagogy of the oppressed. New York, N.Y.: Continuum.

Gage, N., \& Berliner, D. (1991). Educational psychology (5th ed.). Boston, M.A.: Houghton, Mifflin.

Gesell. A. (1948). Studies in child development. Westport, C.T.: Greenwood Press.

Hase, S., \& Kenyon, C. (2000). From andragogy to heutagogy. In Ultibase articles. Retrieved from: http://utibase.rmit .edu.au? Articles/dec00/hase2.htm

Humanist Manifestos I and II. (1973). Washington, D.C: American Humanist Association. 
Hunt, J. M. (1969). The impact and limitations on the giant of developmental psychology. In D. Elkind, \& J. Flavell (Eds.), Studies in cognitive development: Essays in honor of Jean Piaget. New York, N.Y.: Oxford University Press.

Illeris, K. (Eds.). (2009). Contemporary theories of learning. New York, N.Y.: Oxford University Press.

Jarvis, P. (2012). Learning from everyday life. HSSRP, 1(1), 1-20.

Kicthenham, A. (2008). The evolution of Jack Mezirow's transformation learning theory. Journal of Transformative Education, 6 , 103-124.

King, K. (2000). The adult ESL experience: Facilitating perspective transformation in the classroom. Adult Basic Education, 10(2), 69-89.

Knowles, M. S., Holton, E. F., \& Swanson, R. S. (2012). The adult learner: The definitive classis in adult education and human resource development. New York, N.Y.: New Republic Inc..

Knowles, M. (1980). The modern practice of adult education: From pedagogy to andragogy. New York, N.Y.: Follett.

Kurtz, P. (2000). Humanist manifesto 2000: A call for a new planetary humanism. Amherst, N.Y.: Prometheus Books.

Lipoff, P. (2011). Environmental learning theory: Stuff vs. Your child. Retrieved from http://sarahlipoff.com/2011/12/05/environ mental-learning-theory-stuff-vs-your-child/

Marchese F. J. (1995). The place of eugenics in Arnold Gesell's maturation theory of child development. Academic Journal Article: Canadian Psychology, 36(2).

Maslow, A. H. (1943). A theory of human motivation. Psychological Review, 50, 370-396.

Maslow, A. H. (1954). Motivation and personality. New York, N.Y.: Harper.

Maslow, A. H. (1976). Education and peak experience. In C. D., Schlosser (Ed.), The person in education: A humanistic approach. New York, N.Y.: Macmillan.

McLeod, S. A. (2011). Bandura-social learning theory. Retrieved from http://www.simplypsychology.org/bandura.html

Merriam, S. B., \& Caffarella, R. S. (1991). Learning in adulthood: A comprehensive guide. San Francisco, C.A.: Jossey-Bass Publishers.

Merriam, S. B., Caffarella, R., S., \& Baumgartner, L., M. (2007). Learning in adulthood: A comprehensive guide (3rd ed.). San Francisco, C.A.: Jossey-Bass Publishers.

Mezirow, J. (1975). Education for perspective transformation: Women's reentry programs in community colleges. New York, N.Y.: Center for Adult Education, Teachers College, Columbia University.

Perry, W, G. (1999). Forms of ethical and intellectual development in the college years. San Francisco, C.A.: Jossey-Bass Publishers.

Powell, D. R. (1991). Strengthening parental contributions to school readiness and early school learning (Paper commissioned by the Office of Educational Research and Improvement). Washington, D.C.: U.S. Department of Education.

Rogers, C. R. (1983). Freedom to learn for the 1980s. Columbus, O.H.: Charles E. Merrill Publishing Company.

Smith, R. M. (1982). Learning how to learn. Englewood Cliffs, NJ.

Stubblefield, S.W., \& Keane, P. (1994). Adult education in the American experience: From the colonial period to the present. San Francisco, C.A.: Jossey-Bass Publishers.

Thomas, R. M. (1992). Comparing theories of child development (3rd ed.). Belmont, C.A.: Wadsworth Publishing Company.

Turuk, M., C. (2008). The relevance and implication of Vygotsky's sociocultural theory in the second language classroom. RECLS, 5, 244-262.

Weegar, M. A., \& Pacis, D. (2012). A comparison of two theories of learning-behaviorism and constructivism as applied to face-to face and online learning. E-Leader Manila.

Wertsch, J. (1985). Vygotsky and the social formation the mind. Cambridge, U.K.: Harvard University Press. 